\title{
The Political Economy of Grand Strategy in the International System: A comparative Analysis of the United States and China
}

\author{
Iraj Roudgar* \\ Ph.D in Policy Studies, Iran
}

*Corresponding Author: Iraj Roudgar, Ph.D in Policy Studies, Iran

\begin{abstract}
This paper presents a contemporary overview of the United States' grand strategy and political economy since World War I to the post-cold war. It compares the United States' and China's grand strategies in Asia-Pacific. The theoretical framework illustrates the relationships between the grand strategy and political economy in the international system as the result of this review.
\end{abstract}

Keywords: Grand Strategy, Political Economy, International Relations, International Security, Comparative Politics

\section{INTRODUCTION}

The rise of China as a world economic power and modernization of armed forces and increasing military expenditure of the country has brought an undisputed sovereignty over Asia-Pacific regions and thus its emergence a conflict of interests between the countries of the region. As well, the North Korean nuclear crisis casts a shadow over top games in the global security agenda in the world and most obviously, development of the crisis has a significant impact on the international political economy. It's also the major political issue in ASEAN countries, South Korea, Japan, and China as regional and the U.S. as trans-regional power. The United States has come to this conclusion in AsiaPacific that there is the main threat as well as economic opportunities in context national strategic interests which arises from China in the region on a world scale. As the Hegemonic Stability Theory ${ }^{1}$, a single dominant power provides the health of the global economy, but the US liberal internationalism asserts that political and economic liberalism is possible for all other countries. The main question is: Can cooperation persist without the dominance of a single power, such as the United States after World War II? ${ }^{2}$ This study takes a specific view of security and foreign economic policies, and explains the intricate linkages between the political economy and grand strategies of the superpowers.

\section{The Political ECONOMY OF GRAND STRATEGY}

The political economy literature argues that economics alone cannot fully explain the enormous variance across countries in growth and, more generally, in economic outcomes and policy choices, and economic policy is the result of political struggle within an institutional structure. ${ }^{3} \mathrm{~A}$ comparison between the traditional views and three main ideologies of the international political economy and the principal of economic or politics shows that in liberalism, economics and politics are independent and it is committed to a free market or free trade and market competition. The realistic perspective (nationalism and mercantilism) on the international political economy believe that economic activities enhance the power and security of the state. Conversely, in Marxism the theory describes that politics

\footnotetext{
${ }^{1}$ The stability of the international system requires a single dominant state to articulate and enforce the rules of interaction among the most important members of the system. The liberal internationalism considers to hegemonic cooperation in political and economic in the international system.

${ }^{2}$ Robert Keohane 1984. After Hegemony: Cooperation and Discord in the World Political. Author describes the evolution of international regimes as American hegemony in the international political economy in the PostCold War. Study concludes the Cooperation involves mutual adjustment and can only arise from conflict or potential conflict.

${ }^{3}$ Alberto Alesina\& Roberto Perotti. 1994. "The Political Economy of Growth: A Critical Survey of the Recent Literature." The World Bank Economic Review (Oxford University Press) 8 (3): 351-371.
} 
does not have an independent identity and is based solely on the economy. The constructivist view propounds that material interests, which are central to liberal, realist, and Marxist views, are not sufficient to explain patterns of economic interactions or policies, and that economic and political identities are significant determinants of economic achievement. ${ }^{4}$ Thus, the international political economy is struggling for power and wealth which economic factors are vital to increasing military expenditure and distribution of power. ${ }^{5}$

International political economy explains the link between economics and international relations which the international relations is one of the two most important parts of a grand strategy. ${ }^{6}$ Study by Narizy has introduced the three-dimensional typology of grand strategy such as willingness to pay the costs, geographic locus, and willingness to use military force. ${ }^{7}$ Narizy argues that societal groups with different stakes in the international economy and defence spending often have conflicting strategic priorities. $^{8}$

The grand strategy comprises the "purposeful employment of all instruments of power available to a security community" and thus each country pursues different grand strategies at different conditions with different degrees of success. ${ }^{10}$ The modern concept of the grand strategy refers to both military aspects and also a more complex dimension, which consists of the national security doctrine. ${ }^{11} \mathrm{To}$ address these weaknesses in the literature, the grand strategy is redefined consisting of long-term objectives in defence and foreign policies in the state and its role in the international system. ${ }^{12}$

During World War I, the U.S. grand strategy supported Britain and France in the war. ${ }^{13}$ Given liberal ideas in action, US President Woodrow Wilson during the last year of World War I gave the "Fourteen Points" to the US Congress. ${ }^{14}$ As it presented its ideas for a restored world beyond the war, the last point was to create an association of nations for the League of Nations. ${ }^{15}$ Then, the Americans felt they were engaged in a contest with authoritarian great powers who were seeking world domination. ${ }^{16}$ In 1920 , the League of Nations was created mainly to monitor the affairs between countries and to implement and maintain international peace. However, when the league fell due to the outbreak of World War II in 1939, its failure was understood by the liberals because the events seem to contradict their theories. In World War II, America became the Arsenal of Democracy by out producing the Axis led by Germany. ${ }^{17}$ In 1941, the Japanese attack on Pearl Harbour drew the U.S. into the war, which was a sensible one as Germany was the most powerful member of the Axis and

\footnotetext{
${ }^{4}$ It is a summary of my understanding about the traditional school doctrines regarding the principal of economics or politics in the governance and its role in the global system. For example, from mercantilist doctrine the principle is with politics which it's conducted and developed national economy.

${ }^{5}$ For example, the rise of China as a world economic power has brought an opportunity for the country such military modernization and the military policy implications of control the South China Sea.

${ }^{6}$ The second part of a grand strategy is Defence policy. (the conceptual framework)

${ }^{7}$ Narizny, Kevin. 2007. "The Political Economy of Grand Strategy." (Cornell University Press). The author discussed theUS and British experiences during mid-nineteenth to the mid-twentieth centurythat a critical test between the political economy and realist explanations of grand strategy.

${ }^{8}$ Narizny, Kevin. 2017. "American Grand Strategy and Political Economy Theory." Oxford Research Encyclopedias.It is an overview of American foreign policy over the last several decades and argues in different strategic priorities in the US in Bush, Obama administrations, and Trump's electoral coalition which concluded the grand strategy is a product of political economy!

${ }^{9}$ Gray, Colin S. 2017. War, Peace and International Relations: An Introduction to Strategic History. New York City, Park Square, Milton Park, Abingdon, Oxon, OX14 4RN: Routledge 2007 pdf version.

10 Ibid.

${ }^{11}$ Savin, Leonid. 2016. "Grand Strategy | Katehon think tank. Geopolitics \& Tradition." US Grand Strategy,

${ }^{12}$ From my point of view

${ }^{13}$ Ibid.

${ }^{14}$ In January 8, 1918, address to Congress, President Woodrow Wilson proposed a 14-point program for world peace. These points were later taken as the basis for peace negotiations at the end of the war.

${ }_{15}$ The League of Nations was thought up by Woodrow Wilson, the American President during the First World War. It was to be a group of nations that worked together to keep peace.

${ }^{16}$ Lyon, Rod. 2016. Are We Entering a New Era of U.S. Grand Strategy? Foreign Policy Experts RoundTable .

${ }^{17}$ Louis, Morton. 2000. United States Army in World War 2: War in the Pacific, Strategy and Command: The First Two Years. Edited by Estetson Conn. Washington D.C.: Center of Military History
} 
directly threatened the existence of the United Kingdom and Soviet Union. ${ }^{18}$ Since World War II, the U.S. traditional objectives have been to prevent adversaries from dominating the region, maintain access to the region's oil and waterways, and defend and support friendly states. ${ }^{19}$

In the Cold War, America could not defeat the Soviets militarily, so it organized a system of containment to beat them in a longer-term contest of economic and political systems. ${ }^{20}$ Throughout the Cold War, the world was essentially divided between the United States and the Soviet Union. ${ }^{21}$ In October 1962 the Cuban Missile Crisis of was a direct and dangerous confrontation between the United States and the Soviet Union then American guarantee not to invade Cuba and a secret promise to remove its nuclear-tipped missiles from Turkey and the Soviets remove the missiles from Cuba. ${ }^{22}$ In 1983 President Ronald Reagan in a nationwide television address the Strategic Defense Initiative (SDI)/ the Star War which proposed the U.S. strategic defensive system against potential nuclear attacks as originally conceived, from the Soviet Union and helpend the Cold War resulted the collapse of the Soviet.

In the Post-Cold War, the U.S. has done this through a grand strategy of containment; through multilateral agreements, strategic partnerships, arms sales, foreign aid, Arab-Israeli diplomacy, rapiddeployment forces, and intervention to liberate Kuwait. ${ }^{23}$ Then, the United States faced the most favourable prospects ever for the use of American power in the international arena towards the "New World Order" which came first, in common theme in conspiracy theories through an authoritarian world government. In September 1993US grand strategy changed from "Containment to enlargement and engagement," for the Clinton administrations and the policy of expanding the alliance eastward and from that moment NATO expansion became the United States grand strategy in the new world. The objective under Clinton and Bush administrations became that of spreading democracy by expanding the alliances as far as possible among other countries. The American strategy of expanding NATO has managed to place the alliances in just that vulnerable position. ${ }^{24}$ The objective then had been to defend existing democracies against any expansion of Soviet influence.

Then, the U.S. Policies pursued a military presence and possible intervention for two main strategic national interests in security in the world; the Middle East and Asia-Pacific by means of the simultaneous independence and interdependence of different existential threats as the future global conflicts. ${ }^{25}$ The strategy was then developed and efforts were made to strengthen related American alliances to stop further regional expansions of China in Asia-Pacific and Iran in the Middle East as two pivotal regional actors. The policy also pursued the disarmament of the North Korean Nuclear Program and later the strategic patience then strategic accountability in the Korean Peninsula. ${ }^{26}$

In 2015, the United States strategy, shifted from the Middle East towards Asia-Pacific for rebalancing defenses, defending the U.S. alliances, diplomatic relations, and economic resources in the latter region. The type affects military allies in need of military and political support so that foreign economic policies classify military allies and against enemies and other countries. The powers that need such support will pursue discriminatory foreign economic policies in order to pursue the configuration of domestic interests in favour of not only closer economic relations, but also closer

\footnotetext{
${ }^{18}$.Louis, Morton.2000. United States Army in World War 2

${ }^{19}$ Ibid. The Persian Gulf and South China Sea are the most strategically important in maritime transportation and global trade which have significant contribution to the world political economy.

${ }^{20}$ Doherty, Patrick. 2013. "A New U.S. Grand Strategy | Foreign Policy 2013.

${ }^{21}$ Ibid. While the United States and the Soviet Union never confronted each other in battle during the Cold War, many countries served as locations for proxy wars between the superpowers.

${ }^{22}$ Francis J. Gavin 2012 Lessons from the Cuban Missile Crisis.The National Interests.Repercussions of the crisis. Speaking many years later, Khrushchev claimed that he had won the Cuban missile crisis. He had achieved both his aims - America never bothered Cuba again (which is still a Communist country) and the US missile sites in Turkey were dismantled in November 1962.

${ }^{23}$ Mattair, Thomas R. 2013. U.S. Grand Strategy in the Middle East: Is There One? Middle East Policy Council.

${ }^{24}$ John Lewis Gaddis (2009). What Is Grand Strategy? Yale University. The author cited; I don't have much confidence in the ability of universities, as currently organized, to scrutinize theories critically.

${ }^{25}$ Ibid.The Persian Gulf and South China Sea are the most strategically important in maritime transportation and global trade which have significant contribution to the world political economy.

${ }^{26}$ Protects Japan and defends South Koreaagainst North Korea's threats.
} 
political relations. By strengthening domestic support for an alliance, policymakers are harder for their allies than unions. Stronger political relations, in turn, will strengthen the deterrent effect of the alliance. Since the purely strategic benefits of closer ties to them are lower, the powers that can only spend without the support of allies discourage discriminatory policies. ${ }^{27} \mathrm{~A}$ shift in strategic needs explains the variations in the relationship between security considerations and foreign economic policies within alliances over time as well as across alliances. ${ }^{28}$

In April 2015, Beijing successfully completed the construction of infrastructure on an artificial island in the Spratly Islands in the South China Sea and thus virtually designating the previously uninhabitable area its sovereign zone. ${ }^{29} \mathrm{As}$ a part of the strategy, the military expansion and geographical location allowed China's attempts to dominate the South China Sea and extend permanent military presence further in proximity to Southeast Asia. China's current grand strategy first attends to potential threats to vital interests (territorial and integrity). ${ }^{30}$

The $19^{\text {th }}$ Chinese Communist Party (CCP) Congress was held in October 2017 and President Xi Jinping claimed China entering a 'new era'. The Congress approved the 30-yearsnational vision plan to promote the position of China in national, regional, and international development plan where China becomes a more developed country in the space of the next thirty coming years. As Xi vision China's grand strategy is pursuing into 'two-stage of development plan' in the following years. In the first stage, the primary goal is to build on the foundations of China's modern economy from 2020 to 2035. In the second stage, China will seek to become a state with substantial global influence from 2035 to $2050 .{ }^{31}$ China's goal in defence policy has been involved in development a modern maritime military force structure commensurate with its national security and development interests. The air and naval forces must be able to operate jointly and prevail in both conventional and new theatres of operation. ${ }^{32}$ China's military budgets grew by 650 percent between 1996 and 2016, to some US $\$ 143$ billion. ${ }^{33}$ Thus, the major projects implementation system, deepen reform of military science, technology and industry, achieve greater military-civilian integration, and build integrated national strategies and strategic capabilities will bring modernization of armed force in the coming years.

\section{DisCUSSIONS}

The Asia-Pacific is an immense region, covering approximately $22 \%$ of the global land area with over 4.5 billion people by ethnic and cultural diversity. ${ }^{34}$ In the region, the South China Sea is one such essential waterway for the United States and an estimate shows at least $30 \%$ of the world's maritime trade transits, including approximately $\$ 1.2$ trillion in ship-borne trade is bound through the sea for the US annually. ${ }^{35}$ The South China Sea is fast emerging as a major zone of conflict in the Asia-Pacific, especially the South-east Asian geopolitics. The regional disputes involve both island and maritime claims among several sovereign states within the region, namely China, Malaysia, Brunei, Taiwan, Vietnam, and the Philippines. ${ }^{36}$

\footnotetext{
${ }^{27}$ Skålnes, L. 1998. "Grand Strategy and Foreign Economic Policy: British Grand Strategy in the 1930s." World Politics (Cambridge Coer) 50 (4)

${ }^{28}$ Skålnes, L. 1998.

${ }^{29}$ Savin, L. (2017).South China Sea and Geopolitics of Islands. It is not forbidden by the international law and military bases in the isles.

${ }^{30}$ It is a part of their grand strategy to expand territorial seas and implement strategies that support greater access to marine resources.

${ }^{31}$ ZhongFeiteng, 2018. Chinese Academy of Social Sciences.China's grand strategy in a new era. East Asia Forum

${ }^{32}$ The 19th Party Congress: China to have world-class military by 2050

${ }^{33}$ Chatham House, international affairs, V 94,Is 4,1 July 2018

${ }^{34}$ Ibid.For the particular states, the geopolitics provides a supporting discursive context for grand strategy. The South China Sea plays a significant role in the geopolitics of the Indo-Pacific and thus the main corridor between the Indian and Pacific Oceans.

${ }^{35}$ Carl Levin \& Howard P. 2015. The Asia-Pacific Maritime Security Strategy, "Buck" McKeon National Defense Authorization, Department of Defense

${ }^{36}$ The conflict remained the centuries old territorial dispute over possession of some geographical features of this maritime zone, it is gradually transcending the periphery of the inter-state territorial feud and emerging as the driving force of an Asian cold war of the entry-first century.
} 
In response to China activities, the U.S. strategy pursued an effort to strengthen alliances and partnerships in Asia-Pacific to a common security vision and economic concern for the future. This vision does encourage military rebalanced of the United States alliances in the Nations. On the other side, China's grand strategy is pursuing military modernization with a focus on artificial intelligence and maritime security to defend as the main strategic national interests in Asia-Pacific. ${ }^{37}$ The United States' grand strategy in the region is designed to achieve long-term economic and maritime security interests in Southeast Asia and protects Japan and defends South Korea by the presence of the U.S. military in East Asia. ${ }^{38}$ To achieve the goals, the U.S. established a monitoring strategy that can be supported by navigation program and multilateral coalition under the uncertain conditions in the region. The U.S. defence strategy towards the nation rebalances to the Asia-Pacific regions not only revalidates this posture but also marks a shift that stresses the necessity for far-reaching naval and air force capabilities. ${ }^{39}$ The "America First" policy can be US new grand strategy it repeats by the president Trump. This slogan will put negative effects on the US foreign policy and diplomacy in international relations, especially in relation to cooperation with European Union in resolving global conflicts.

The administrative divisions of China has never clearly articulated a coherent version of their grand strategy in front of the world, it's symbolic of their political behavioural intention unlike the US foreign policy. As historical example, Mao Zedong used to like to tell his associates that the offshore islands of Quemoy and Matsu were a noose around the neck of the Chinese Nationalists and their American allies, which he could tighten or relax whenever he found it useful. ${ }^{40}$ In the international system, Chinese don't have interest in taking part and presence of participating some of the world political crisis or become a state with substantial global influence such international counter-terrorism and human right crises unlike other permanent members of the United Nations Security Council, however active in other areas of global issues may have response to Climate Chang in Paris deal and economic presence in Africa. The general policy has been so far focused on economic development such investment in the Silk Road. ${ }^{41}$

In Asia-Pacific region, the Chinese provocative behaviour with a cautious strategy driven by the maritime capabilities has increasingly developed more domination in the world's maritime trade transits in the South China Sea over the past two decades (economic corporation and political isolation). It's clear the political economy adopted in the international system as Chinese foreign economic policy which resulted as Realistic perspective in the new world order. The strategy is designed to foster favourable conditions for continuing China's modernization while also reducing the risk that others will decide a rising China is a threat that must be countered. ${ }^{42}$ The modernization of armed forces and increasing military expenditure of China has resulted in the naval expansionism and building of artificial islands which developed tensions towards the regionally order in the region. The military reform will lead to heightened tensions with China's neighbouring countries, including Japan

\footnotetext{
${ }^{37}$ For instance, Alibaba announced plans to invest $\$ 15$ billion in research over 3 years to build seven labs in four countries that will focus on quantum computing and AI.According to a Narrative Science, just $38 \%$ percent of the companies surveys used artificial intelligence in 2016 - but by 2018, this percentage will increase to $62 \%$. IDC estimated the artificial intelligence market will grow from $\$ 8$ billion dollars to more than $\$ 47$ billion by 2020.

${ }^{38}$ The US may have to come to the defense of an even larger number of European alliesagainst the North Korea's missiles threats. (Deutsche Wellereported based on Germany's foreign intelligence agency)

${ }^{39}$ Ibid.In 2015, Obama has visited many countries of the region, he was staged to call attention to a defense cooperation agreement

40 John Lewis Gaddis (2009). What Is Grand Strategy? Yale University, When the Chinese Communists (PRC) gained control of mainland China in 1949 from the Nationalists, their attempts to take over the offshore islands failed and exiled Nationalist leader Gen. Chiang Kai-shek continued to exercise sovereignty over Taiwan and Quemoy-Matsu plus the Tachens.Mao Zedong's description of North Korea's relationship with China is typically mischaracterized as being as close as "lips and teeth.

${ }^{41}$ In 2013, President Xi Jinping announced that the Silk Road would be reborn as the Belt and Road Initiative, the most ambitious infrastructure project the world has ever known - and the most expensive.

${ }^{42}$ Goldstein, A. (2005). Rising to the Challenge: China's Grand Strategy and International Security. Stanford: Stanford University Press. This book describes and explains the grand strategy China's leaders have adopted to pursue their country's interests in the international system of the 21 st century.
} 
in the East and USA in the South China Sea. ${ }^{43}$ A comparison between the two military world powers indicates that China's military capacities are not formally equal to the United States at a global level. In addition, the geopolitics of rare earths and geographical location in the political world maps are the significant determinants which indicate the limitations of Chinese grand strategy to achieve long-term security objectives. Nevertheless, dominance of the South China Sea is a vital part of Chinese grand strategy in the Asia-Pacific region.

The conflicting security and conflicts of policy objectives at the regional and global levels have brought uncertainty, distrust, and fear in underlie the U.S.-China relations, both countries may be unable to make and keep credible commitments to each other. According to the Hegemonic Stability Theory, the health of the global economy is somehow dependent on the presence of a single dominant power. ${ }^{44}$ Conversely, the liberal internationalists believe that the US should neither save, nor spend its superiority without a need to. The US should invest in, and even share their superiority with other countries and alliances. And it should be used for clear liberal purposes, because liberal internationalism asserts that political and economic liberalism is possible for all other countries as well. ${ }^{45} \mathrm{~A}$ historical review indicates that Americans' long-term diplomacy, isolation, and economic sanctions also working as a strong instrument in the US foreign policy which helps to achieve the policy objectives as the main section of their grand strategy, earlier military intervention. The U.S. economy remains the largest in the world in terms of nominal GDP and it is also allowed to use the sanction's stick as an effective tool in force by foreign policy in the international system. ${ }^{46}$ At the same time, China is America's largest trading partner. ${ }^{47}$ The rise of China as biggest world exporter has brought an opportunity for Chinese foreign policy and ascends conflict in the trade dimension for the US. The U.S. trade deficit with China was $\$ 375$ billion in 2017. As Keohane (1984) the cooperation involves mutual adjustment and can only arise from conflict or potential conflict. ${ }^{48}$ Thus, these questions now arise; China appears to be a strategic partner to cooperation in the international system? And how do explain the US-China relation in the international system in the next coming years: Cooperation, Competition, or Conflict?

\section{CONCLUDing REMARKS}

The United States' grand strategy towards China to diminish the economic and political growth of the country as well as Chinese alleged hegemonic ambition in Asia-Pacific. The American strategy is replied by Chinese cautious strategy in Southeast Asia. It does seem that the United States grand strategy is designed for two main strategic national interests in security in the Asia-Pacific region firstly, a containment policy against Chinese dominance in Southeast Asia and, secondly, defending the U.S. alliances against North Korea's threats in East-Asia. On the other side of the conflict of interests, China policy also pursues two long-term objectives; displacing the United States as the preeminent power in the Western Pacific, and consolidating Asia into an exclusionary bloc deferring to Chinese economic and foreign policy interests. Thus, both of the grand strategies have focused on control and dominance over the South China Sea and will be the major political issue in the strategic competition or conflict of strategic interests. The military hegemony in the South China Sea is strategic priorities in the United States and China thus the regional geopolitics has made a significant contribution to the international political economy. In other words, there is a conflict of strategic interests between a pivotal regional actor known as world's largest exporter and the trans-regional power with an advanced military technology.

\footnotetext{
${ }^{43}$ China's military reforms to "Win A War" and overtake the US revealed in leaked memo. https://www.express.co.uk > News > World

${ }^{44}$ (Kindleberger, The World in Depression, 1929-1939:Revised and Enlarged Edition 1986) Chapter 3

${ }^{45}$ (Savin, Grand Strategy | Katehon think tank. Geopolitics \& Tradition 2016)

${ }^{46}$ Countries sanctioned by the US: Burma, Ivory Coast, Cuba, Iran, North Korea, Syria and specific people and organizations in the Balkans, Belarus, Congo, Iraq, Iran, Liberia, Sudan and Zimbabwe

47 The U.S. trade deficit with China was $\$ 375$ billion in 2017 . The trade deficit exists because U.S. exports to China were only $\$ 130$ billion while imports from China were $\$ 506$ billion. The United States imports consumer electronics, clothing and machinery from China.

48 Donald Trump "Last year we lost $\$ 500$ billion on trade with China."http://www.politifact.com/truth-ometer/statements/2018/mar/28/donald-trump/did-us-have-500-billion-deficit-china-2017/
} 
The Figure below illustrates the association between the grand strategy and political economy in the international system. As a classic issue, there needs to be a close integration between the diplomatic and the military in the grand strategy. The military and the diplomatic powers have become intertwined in the grand strategy. Thus, foreign and security policies in grand strategy are associated with the political economy. Although other independent components such as regional geopolitics and strategic depth, technology and nuclear capability, economic capacity, population demography and political culture which are significant determinants of a grand strategy to achieve national interests and policy objectives.

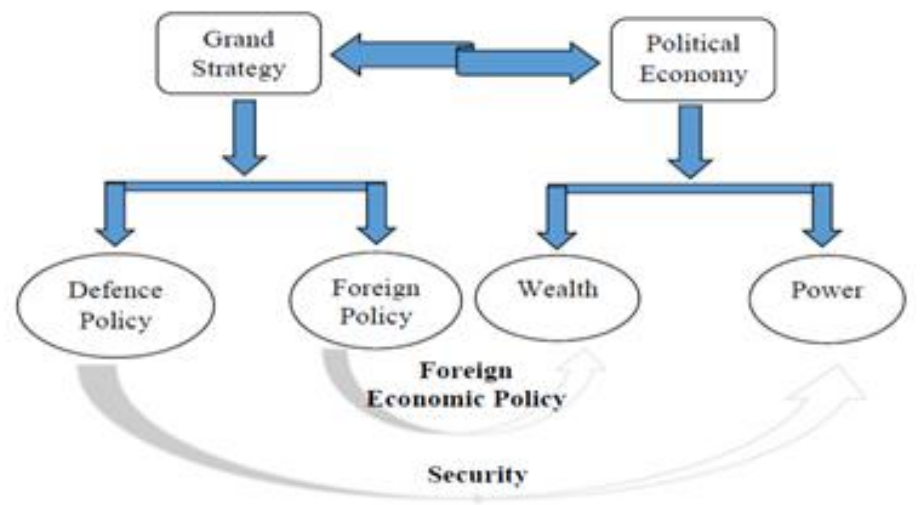

\section{IMPLiCATIONS OF THE FINDINGS- POLICY AND MANAGERIAL}

The political challenge is sustainable in the new world's crisis with a focus on the South China Sea between the superpowers. An adoption of the maritime law (admiralty law) and territorial waters should be a priority in the world system that is associated with peace and enhance international security in the case of South China Sea. The maritime disputes and territorial claims should be resolved through negotiation between the regional players and not military interventions. A most important point for the superpowers is the global wealth passes through the regional geopolitics of the South China Sea and defense policy of the two sides has a significant contribution to the international political economy as well as international security. Although maritime security in the South China Sea alike the Persian Gulf remained as a common strategic interests between the superpowers as well as among the regional players.

\section{BIBLIOGRAPHY}

[1] Alberto Alesina \& Roberto Perotti. 1994. "The Political Economy of Growth: A Critical Survey of the Recent Literature." The World Bank Economic Review ( Oxford University Press) 8 (3): 351-371. http://www.jstor.org/stable/3989954.

[2] Doherty, Patrick. 2013. "A New U.S. Grand Strategy.Foreign Policy 2013." The Magazine. Accessed May 1, 2017. http://foreignpolicy.com/2013/01/09/a-new-u-s-grand-strategy/

[3] Goldstein, A. (2005). Rising to the Challenge: China's Grand Strategy and International Security. Stanford: Stanford University Press. Accessed Feburary 23, 2018

[4] Gray, Colin S. 2017. War, Peace and International Relations: An Introduction to Strategic History. New York City, 2 Park Square, Milton Park, Abingdon, Oxon, OX14 4RN: Routledge 2007 pdf version. Accessed May 18, 2017.

[5] Kindleberger, C. P. (1986). The World in Depression, 1929-1939 (Revised and Enlarged Edition ed., Vol. 3). California: University of California Press. Accessed Feburary 8, 2018

[6] Louis, Morton. 2000. United States Army in World War 2: War in the Pacific, Strategy and Command: The First Two Years. Edited by Estetson Conn. Washington D.C.: Center of Military History. Accessed Julay 20, 2017. Pdf Version.

[7] Lyon, Rod. 2016. Are We Entering a New Era of U.S. Grand Strategy? Foreign Policy Experts RoundTable . Accessed July 2, 2017. http://nationalinterest.org/blog/the-buzz/are-we-entering-new-era-usgrand-strategy-15674.

[8] Mattair, Thomas R. 2013. U.S. Grand Strategy in the Middle East: Is There One? Middle East Policy Council. Accessed July 7, 2017. doi:Volume XX, No1.

[9] Narizny, Kevin. 2017. "American Grand Strategy and Political Economy Theory." Oxford Research Encyclopedias (Politics). Accessed January 9, 2018. doi:10.1093/acrefore/9780190228637.013.316. 
The Political Economy of Grand Strategy in the International System: A comparative Analysis of the United States and China

[10] Narizny, Kevin. 2007. "The Political Economy of Grand Strategy." (Cornell University Press) 344. Accessed 13 January, 2018. http://www.cornellpress.cornell.edu/book/?GCOI=80140100678200

[11] Robert, Keohane. 1984. "After Hegemony: Cooperation and Discord in World Political Economy". Princeton University Press.Pdf Version. Accessed May17, 2018

[12] Savin, Leonid. 2016. "Grand Strategy| Katehon think tank. Geopolitics \& Tradition." US Grand Strategy, Accessed July 20, 2017. http://katehon.com/article/us-grand-strategy.

[13] Savin, L. (2017). South China Sea and Geopolitics of Islands. Katehon think tank.Accessed Feburary 22 , 2018, from http://katehon.com/1087-south-china-sea-and-geopolitics-of-islands.html

[14] Skålnes, L. 1998. "Grand Strategy and Foreign Economic Policy: British Grand Strategy in the 1930s." World Politics (Cambridge Coe) 50 (4): 582-616. doi:10.1017/S0043887100007371.

Citation: Iraj Roudgar. "The Political Economy of Grand Strategy in the International System: A comparative Analysis of the United States and China". International Journal of Political Science (IJPS), vol4, no.3, 2018, pp.14-21. doi:http://dx.doi.org/10.20431/2454-9452.0403003.

Copyright: (c) 2018 Authors. This is an open-access article distributed under the terms of the Creative Commons Attribution License, which permits unrestricted use, distribution, and reproduction in any medium, provided the original author and source are credited. 